\title{
What Is Sex-Positive Feminist Pornography? The Answer Is in the Question
}

\author{
Emily E. Prior \\ College of the Canyons and Center for Positive Sexuality (Los Angeles)
}

\section{Introduction}

Being "sex positive" seems to be the new catch phrase -- of organizations, policies, educational programs, and even pornography - but what does this really mean in the context of porn? In an industry that has capitalized on trends in media, it is not surprising that pornography has caught on to the idea that positive sexuality content sells.

Concurrently, we have various "brands" of feminism arguing differing sides of political issues, from women in the workplace versus stay-at-home-moms to, again, pornography. Since the beginning of the "sex wars" in the 1970s, feminists have found themselves working against other feminists (Liskova, 2009), not just "the patriarchy." Some feminists, particularly radical feminists, believe that sex and sexual expression, especially heteronormative sexual expression, is hurtful to women and puts them in the role of the mindless, subordinate sex toy (Dworkin, 1989). Other feminists feel that women having power and space in society means allowing women, all women, to freely choose the types of sex, relationships, and sexual fantasies that work for them, whether or not other women agree with their choices (Dodson, 2013).

During the 1970s sex wars, a few women engaged in a type of anarchy. These few women began to create feminist pornography, pornography made for and by women, utilizing storylines, characters, sets, and sexual acts that were presumably more attractive to female porn users. Fueled by their own fantasies, as well as popular pornography of the time, these feminist pornographers created a niche market where female sexual expression was the order of the day, and a dominantly heteronormative male audience was not the driving force behind the work. Producers like Candida Royalle incorporated actual couples and their sexual preferences into the work, as well as paved the way for bodies and orientations outside of gender and sexual binaries to embrace sexual expression for the screen, for themselves, and for the viewers (Royalle, 2013).

Moving ahead several decades, producers like Tristan Taormino continue this tradition of feminist pornography, allowing actors to choose their partners, define the parameters of a shoot, and possibly even take part in the larger economy of porn production. This set of practices is now defined as "sex-positive feminist pornography" (Taormino, 2013). So, is this truly a new style of feminist pornography? If so, how do we identify it as such?

\section{Defining Feminist Pornography}

From a radical feminist perspective, feminist pornography cannot possibly exist. From this perspective all pornography is by definition anti-woman, regardless of the intended audience, sex or gender of the producers, or the behind-scenes business practices. However, if 
this were true, many women, and many feminists (regardless of gender) would find themselves at a serious loss for sexual expression. Radical feminists wanting to quash the pornography industry in the name of freeing women from sexual slavery has actually worked to silence or at least challenge women who enjoy a variety of sexual possibilities that may or may not fit the status quo. As Willis (1992, p. 221) points out, if porn is the enemy, “...the result will be to make a lot of women ashamed of their sexual feelings and afraid to be honest about them. The last thing women need is more sexual shame, guilt, and hypocrisy - this time served up as feminism." How could this possibly be pro-woman?

On the other hand, from a third-wave (and the up-and-coming fourth-wave) feminist perspective, feminist pornography not only exists but is thriving within an industry that was once primarily dominated by men. Women have taken control of their sexual desires and porn production, creating sexy images and storylines that may be more appealing to women, or at least some women. It is important to understand that porn created primarily for and by men also appeals to some women, and there's nothing wrong with that. Women are increasingly being given permission to enjoy what turns them on. And the feminist pornography movement has been adding to the spectrum of possibilities by including bodies, orientations, relationships, acts, and work practices previously not available through more mainstream pornography (Penley, Shimizu, Miller-Young, \& Taormino, 2013).

Within this movement, there seem to be some distinctions that define what feminist pornography is and what it is not. Terms like "authentic", "real", "consent", and "fair trade" dominate the discussion on differentiating feminist pornography from other genres. The idea is that these variables may not be inherent in mainstream porn production, but are the crux of feminist porn production.

Both Young (2014) and Maina (2014) discuss how authenticity and realism are key components of feminist pornography. This is defined as performers having control over the sexual content within a scene or entire production, based on their own desires, fantasies, and partners. This is also expressed through the portrayal of a variety of bodies and gender presentations that seems to be lacking in mainstream pornography. Although even staged performances with mainstream porn actors can be appealing to a wide audience and is not necessarily unreal or inauthentic, feminist pornography offers a space for viewers and performers alike who may not fit within the normalized categories of sexy and appealing portrayed by mainstream porn. This space gives permission to those who do not fit, are outside of sexual and gender binaries, are not considered normal or attractive in mainstream society much less within pornography; a place to be sexy and to explore sex on their own terms.

Consent is another theme prevalent in feminist pornography. This is not to imply that nonconsent is the order of the day in mainstream pornography, but explicit, dynamic consent on many levels is made clear through many feminist production companies. Young (2014) discusses how she gives performers choices about who they work with, what types of activities they will engage in, even lube preferences. This establishes not only sense of personal freedom, but also a workplace in which performers establish and maintain discussions of consent around each aspect of the work day. That a performer engaged in a particular act with another particular performer on a particular day does not mean that same thing will occur on the next work day, or even in the 
next scene. Young (2014) discusses this as not only valuing the people she works with but also establishing a norm of negotiating for healthy sexual expression.

Another key term interconnected with sex-positive feminist pornography is "fair trade". Although the term is used widely when discussing foreign politics or global economies, fair trade practices within the porn industry (or most American, nonagricultural industries) are not at all common. This concept revolves around the idea that the actual producers of a product (the workers, the farmers, the tradespeople) are given a fair market price for their work in an attempt to even the playing field in the larger economy by sharing the wealth with them, as well as creating sustainable products and business practices (Linton, 2012). In the context of feminist pornography, fair trade plays out in unique ways.

Mondin (2014) points out that feminist pornography, as an outgrowth of the punk subculture's do it yourself (DIY) ethic, is meant to create and uphold a sustainable product and community. This is not just about making money, but about supporting one another's sexual expressions. This fair-trade model of pornography production may allow performers and producers to collaborate on projects, often even overlapping their roles, as well as adopting economic practices that allow everyone a slice of the pie.

\section{Where Positive Sexuality and Feminist Pornography Converge}

In light of the above discussion, is feminist pornography inherently sex positive? With dimensions such as consent, authenticity, and free trade as hallmarks of feminist pornography, how does this match with a positive sexuality perspective? According to the multidisciplinary framework of positive sexuality outlined by Williams, Thomas, Prior, and Walters (2015), there seem to be many overlapping qualities. This framework discusses eight specific dimensions of positive sexuality, most of which seem to concur with the ethics, practices, and production of feminist pornography.

Positive is discussed as referring to strengths, wellbeing, and happiness, as well as there being a recognition of how multifaceted human sexuality really is (Williams, Thomas, Prior, \& Walters, 2015). From a feminist pornography perspective, performers are encouraged to bring their real world experiences and interests to the set, coming from a foundation of what works for them and supports their sexual and personal wellbeing (Maina, 2014; Mondin, 2014).

Open and honest communication is also a hallmark of positive sexuality (Williams, et al., 2015) and feminist pornography (Young, 2014). Creating a safe work environment that is upheld by explicit consent and allows performers and producers to discuss content, action, filming techniques, and even distribution methods encourages a level of communication that is necessary, promotes safety and wellbeing, and coincides with ethical standards of practice.

Acknowledging the multiple social levels of how work is manufactured, produced, and distributed, as well as how most Americans tend to identify personally with their professions, is another aspect of both feminist pornography and positive sexuality. According to Williams, et al. (2015) "... sexuality is an integral part of who we are as people..." When we layer that with how integral our professions have become as identity markers, those working in professions where 
sexual identities and work identities overlap must be especially aware of how important both of these aspects are to our overall wellbeing.

Encouraging professional ethics is another aspect both of these models have in common. Fair trade practices, sustainability, and supporting performers' personal rights seems common across the literature on feminist pornography (Comella, 2013; Mondin, 2014; Taormino, 2013). From a positive sexuality perspective, working from the ethics outlined in various helping professions as well as others that make clear an ethical standard of practice, "positive sexuality... promotes the voice, needs, choices, experiences, and life of every individual" (Williams, et al, 2015 , p.4) This seems emblematic of the philosophy behind feminist pornography as well.

One other aspect that these perspectives have in common is that of peacemaking. Although by no means easy, peacemaking begins from a place of safety and acceptance, allowing people to be who they are at this time, without judgment or fear. Feminist pornographers also espouse a peacemaking philosophy, from creating sets and production companies that give voice to various sexualized persons as well as creating products that allow consumers the opportunity to feel supported, acknowledged, and sexy.

\section{Conclusion}

Theoretically, feminist pornography is consistent with a positive sexuality model. From fair trade practices to advocacy of performers' and consumers' interests, feminist pornography is becoming an icon of the positive sexuality movement. Even though not all brands of feminism are sex positive, it seems that feminist pornography may very well be.

Researchers should consider interviewing and observing more feminist producers and performers about what happens on set, both in front of and behind the camera. It should also be noted that there may be some producers and performers who do not identify as women but do identify as feminists, and interviewing them may lead to some very interesting perspectives about the present and future of feminist pornography production. Also, conducting a content analysis of the available feminist pornography may allow us to see if this genre truly lives up to the dual expectations of positive sexuality as well as feminism.

Comella, L. (2013). From text to context: Feminist

\section{References}

porn and the making of a market. In

Taormino, T., Shimizu, C., Penly, C., \&

Miller-Young, M. (Eds.) The feminist porn

book (pp. 79-93). New York, NY: the

Feminist Press.

Dodson, B. (2013). Porn wars. In Taormino, T., Shimizu, C., Penly, C., \& Miller-Young, M. (Eds.) The feminist porn book (pp. 23-31). New York, NY: the Feminist Press.

Dworkin, A. (1989). Pornography: Men possessing women. New York, NY: Dutton.

Linton, April (2012). Fair trade from the ground up: New markets for social justice. Seattle, WA: University of Washington Press.

Liskova. K. (2009). Feminist sex wars. In O'Brien, J. (Ed.) Encyclopedia of gender and society (pp. 316-318). New York, NY: Sage Publications.

Maina, G. (2014). After the feminist porn book: further questions about feminist porn. Porn Studies, 1:1-2, 182-185.

Mondin, A. (2014). Fair-trade porn + niche markets + feminist audience. Porn Studies, 1:1-2, 189192.

Penley, C., Shimizu, C., Miller-Young, M., \& Taormino, T. (2013). Introduction: The 
politics of producing pleasure. In Taormino, T., Shimizu, C., Penly, C., \& Miller-Young, M. (Eds.) The feminist porn book (pp. 9-20). New York, NY: the Feminist Press.

Royalle, C. (2013). "What's a nice girl like you...?"

In Taormino, T., Shimizu, C., Penly, C., \& Miller-Young, M. (Eds.) The feminist porn book (pp. 58-69). New York, NY: the Feminist Press.

Taormino, T. (2013). Calling the shots: Feminist porn in theory and practice. In Taormino, T., Shimizu, C., Penly, C., \& Miller-Young, M. (Eds.) The feminist porn book (pp. 255-264). New York, NY: the Feminist Press.

Williams, D J., Thomas, J., Prior, E., \& Walters, W. (2015). Introducing a multidisciplinary framework of positive sexuality. Journal of Positive Sexuality, 1:1, 1-6.

Willis, E. (1992). Beginning to see the light: Sex, hope, and rock-and-roll. Twin Cities, MN: University of Minnesota Press.

Young, M. (2014). Authenticity and its role within feminist pornography. Porn Studies, 1:1-2, 186-188. 